\title{
DAIRY COOPERATIVES IN THE STATE OF MINAS GERAIS, BRAZIL: A SOCIOMETRIC STUDY
}

\author{
Warlei Tana* \\ José Marcos Carvalho de Mesquita** \\ Custodio Genesio da Costa Filho***
}

\begin{abstract}
Cooperation has always existed in human societies. In fact, humans cooperate to survive and to overcome economic, political or social crisis. Cooperativeness emerged for a better life quality in the face of adversity. Factors such as marketing, cost control, diversified portfolio, management, associations, partnerships, attention to consumer market and to cooperative members have become a winner strategy when it comes to competition in domestic and foreign markets to ensure human survival. Current study constructs a sociogram of dairy cooperatives of the state of Minas Gerais, Brazil. Results reveal low density, centralization degree and cohesion index, or rather, most relationships are weak ties. The essay's main contribution is the identification of a pattern of relationships between dairy cooperatives. As managerial contribution, the development of a plan to strengthen ties between cooperatives, led by state cooperatives organization, is proposed.
\end{abstract}

KEY WORDS: Cooperatives; Social Networks; Sociometry.

\section{COOPERATIVAS DE LÁCTEOS NO ESTADO DE MINAS GERAIS, BRASIL: UM ESTUDO SOCIOMÉTRICO}

RESUMO: A cooperação sempre existiu nas sociedades humanas. De fato, os humanos cooperam para sobreviver e superar a crise econômica, política ou social. A cooperação emergiu para uma melhor qualidade de vida diante das adversidades. Fatores como marketing, controle de custos, portfólio diversificado, gestão, associações, parcerias, atenção ao mercado consumidor e membros da cooperativa tornaram-se uma estratégia vencedora quando se trata de concorrência

\footnotetext{
* Doutor em Administração, Docente da Unipam. Universidade Fumec, Unipam. Brasil.

** Universidade FUMEC, Faculdade de Ciências Econômicas, Administrativas e Contábeis. Brasil.

E-mail: jose.mesquita@fumec.br

*** Doutor em Administração, Docente da Universidade Federal de Viçosa (UFV). Brasil.
} 
nos mercados interno e externo para garantir a sobrevivência humana. O presente estudo constrói um sociograma de cooperativas leiteiras do estado de Minas Gerais, Brasil. Os resultados revelam baixa densidade, grau de centralização e índice de coesão, ou seja, a maioria dos relacionamentos é fraca. A principal contribuição do ensaio é a identificação de um padrão de relacionamento entre as cooperativas de laticínios. Como contribuição gerencial, propõe-se o desenvolvimento de um plano para fortalecer os laços entre as cooperativas, liderado pela organização das cooperativas estaduais.

PALAVRAS-CHAVE: Cooperativas; Redes Sociais; Sociometria.

\section{INTRODUCTION}

Cooperativism, foregrounded on its principles, has become a plausible alternative to the new economic model born in the nineteenth century: capitalism. As from the evolution of the Rochdale Equitable Pioneers Society, the idea of cooperation has new concepts. What erstwhile happened in the form of momentary gatherings with specific goals has ended up making something lasting, with extremely positive results for everybody. Cooperativism has emerged as a movement, a way of life, a socioeconomic model, which integrates economic development and social welfare, foregrounded on democracy, solidarity, independence and freedom as fundamental references. Cooperatives became a system based on a group of people and not of capital, where common endeavor conducted in any activity aimed towards the needs of the group and not the financial result. Joint prosperity, not individual richness, are its aims (OCB, 2004).

According OCB (2004), cooperativism in Brazil has its roots in the midseventeenth century when the Jesuits fathers initiated collective work directed towards the "persuasion" of indigenous peoples in the practice of Christian love and mutual cooperation. The first cooperative institutions established in Brazil were consumption cooperatives to distribute products / services to their shareholders, seeking the best possible prices and quality. Agricultural and rural credit cooperatives were founded from this type of institution, mainly in the southern region of the country. Further, other types of cooperatives, such as production, employment and educational cooperatives, were established (OCB, 2004). 
Cooperatives are currently of great social importance and highly responsible for agricultural development. Importance is even greater in the case of dairy cooperatives due to the fact that the sector is formed by thousands of small producers with little bargaining power. Carvalho (2003) points out that this type of sector has some limitations, since goods may be stored for short periods only and they have little protection on financial markets.

According to Antonialli (2000), cooperatives have difficulties in competing with private companies due to slowness in decision-making, poor marketing, few innovations, isolation from new organizational forms and lack of professional management. The author adds that these negative factors should be further exploited in cooperatives, since they could compensate the lack of technical capacity of their managers when they join efforts on ties with industries and organizations. They would thus improve the transmission of knowledge, achieve lower costs, increase capacity on the market, minimize loss risks when the government fails in incentives and goodwill.

Taking into consideration aspects for the better management of cooperatives, Antonialli (2000) and Oliveira (2003) highlight strategic administrations issues by avoiding isolation and participating in well-managed and result-oriented companies. Granovetter (1973) points out that contacts or ties may be beneficial to cooperatives. The author conceptualizes ties as the combination of time, emotional strain, close relationship, confidentiality, access, reference interests, mutual trust and service.

Carvalho (2003), Oliveira (2003) and Antonialli (2000) maintain that participation in social networks is crucial for the development of cooperatives. On the other hand, these authors state that cooperatives, especially in the dairy segment, have remained isolated. Therefore, certain issues should be faced: what kind of relationship dairy cooperatives keep? At what intensity cooperatives take part in social networks? Is there any cooperative that plays a central role in the network? Current study evaluates the relationship among dairy cooperatives. Specifically, the authors have built a sociogram of the dairy cooperatives of the state of Minas Gerais, Brazil, identifying: density; geodesic distance; cohesion, number of expanding borders and number of cliques. Furthermore, they assessed the strongest among the most connected cooperatives on the network and identified the level and characteristics of social relations between them. 


\section{LITERATURE REVIEW}

\subsection{SOCIAL NETWORK}

The analysis of social network is vast, complex and difficult to measure (Leavitt, 1951). According to Hummon, Doreian and Freeman (1990), studies in measurements of social networking began with publications by Bavelas in 1948, and by Leavitt in 1951 .

According to Castells (2005), a network is the formal structure and an interconnected system of nodes. In formal language, nodes are the points where the curve intersects itself.

Grandori and Soda (1995) argue that networks play an important role in the economic environment, regulating the operations of complex transactions and inter-organizational cooperation therein. The authors add that social networks occur in different formats, among which are the inter-firm, joint ventures, franchising, consortium, trade agreements and personal relationship.

Balancieri (2010) highlights that social network analysis allows assimilate relations' movement, distinguishing the flow of information, resources and actors. The author conceptualizes actor as a social unit of different types, such as: an individual, an organization / institution / organization, or even a set of social units. Therefore, the concept of actor is flexible, with different levels of aggregation, thus favoring suitability for different research problems and the comprehension of the complexity of the environments and their interactions.

According to studies by several authors, including Vale (2006), networks may be a source of power and resources. Thus, Barney et al. (2001) suggest that a sustainable competitive advantage of a company derives from its resources and inimitable capabilities which are difficult to replace and which may be tangible or intangible. Among these attributes, the authors listed: bureaucracy of the organization, knowledge management, the ability of managers to turn their knowledge into results, control of information and knowledge.

The analysis of the dynamism and functionality of networks, their influence in the new format of organizations, leads to various discussions on the possibility of 
joining several concepts to issues in Cooperativism. Thus, networks may be seen as essential mechanisms for cooperation among economic agents.

By analyzing the interrelationships within and outside cooperatives and the importance of social networks in the dynamism of today's organizations, some issues may be highlighted: the performance of cooperatives; which factors lead cooperatives to have greater competitive advantage in the marketplace; what is the role of leaders in this context; what should managers do to improve the performance of cooperatives and their positioning on the market; the social network as a competitive advantage in cooperatives; how social capital may be transformed into resources and benefit institutions.

Even though they are not profit-aimed, these institutions need to adapt to various changes in the market. Antonialli (2000) states that cooperatives must avoid isolation of their management process and must monitor the market in which they operate with modern techniques and participatory management. Social networks are tools to facilitate the performance of cooperatives, streamlining business processes, reducing costs and facilitating the interaction of individuals who work inside and outside the organization.

\subsection{SOCIOMETRY}

Sociometry is a concept of positive or negative relationships, involving bonds of family, friends or even acquaintances. Data analyzed by sociometry are presented in the form of a matrix, featuring rows for issuer actors (directional) and columns for the actors who get some action (given the contact). The sociogram (graphs with nodes and lines) and the matrixes (measurement data derived from relationships of the graphs) were used by Jacob Moreno in 1934, in interpersonal interaction evaluation (Wasserman; Faust, 2007).

According to Marsden (1990), the data of a network are the set of all ties that bind a population of a closed network (networks of individuals or institutions with strong ties), or the set of ties around sampled units (example: an egocentric network datum). Such data may be obtained by a survey with questionnaires, files and observation (ethnographic). 
The density measure of a network means the maximum lines that may be connected to a node (actor) (Marsden, 1992; Wasserman, Faust, 2007). It is the ratio of existing links in the network for the number of possible ties (actors). A dense network indicates the velocity information circulates.

The maximum number of lines on a chart is determined by the number of nodes (actors) and the set of lines in a graph is its density. Density may be calculated by the formula: $\Delta=2 \mathrm{~L} / \mathrm{g}$ (g-1) $[\mathrm{L}=$ line; $\mathrm{g}=$ nodes (actors)]. Density ranges from 0 to 1 , or rather, 0 if there are no lines in the graph and 1 if all possible lines are present in the graph (Wasserman; Faust, 2007; Scott, 1987; Brass; Burkhardt, 1998)

Another measure is the centrality that addresses the number of ties that an actor is involved, regardless of being sent or received. In the case of measuring prestige, the amount of bonds that the actor receives is analyzed, showing that it is a reference by other actors in their environment.

The average nodal degrees on a network may be evaluated by the equation: average degree $=2 \mathrm{~L} / \mathrm{g}$, where $\mathrm{L}$ is the number of lines and $\mathrm{g}$ is the amount of nodes (actors). If all the degrees of all the nodes (actors) are equal, there is a regular graph with zero standard deviation. When the nodal degree varies, it means that the actors represented by nodes have different activities. The nodal variability is also a measure of centrality of the graph.

The geodesic distance referenced in a social network analysis is the range of an actor to another (from one node to another). It is the shortest distance between two actors and infers the degree of cohesion and influence of one over the other. The geodesic distance allows us to evaluate how long it takes for information to move in that network (Brass; Burkhardt, 1998; Krackhardt, 1998).

The network diameter is the larger geodesic distance at the network and shows how many steps are required so that information reaches the extreme point of the network. The diameter is the distance from one actor at one extreme to another actor on the opposite end of the network. It reports on the number of steps required to go from one extreme to another extreme of the network, or rather, for an information to cross the network, evaluating the network's size (Wasserman; Faust, 2007).

Other dimensions listed on a network are cohesion index and cliques. 
The cohesion index comprises subgroups which are in constant contact, forming a strong group within the social-networking, for example, a group of immigrants living in a particular neighborhood. The network neighborhood coexists with this group, which will keep the customs of their homeland within the culture of the host country. Its value varies from 0 to 1 : the closer to 1 , the greater the cohesion of the network and more committed to the norms and behavior rules are its members; they may even reach the coercion of some actors over others (Lin, 1982; Wasserman; Faust, 2007). The speed of propagation of information in the network is also linked to its cohesion (Brass; Burkhardt, 1998; Krackhardt, 1998).

A clique is a group formed by three or more adjacent players who are close to one another. Cliques are linked by socioeconomic, religious, cultural, and other issues (Wasserman; Faust, 2007; Scott, 1987; Brass; Burkhardt, 1998; Krackhardt, 1998).

Border expanders, or bridges, are those that, if removed, will provoke a reduction in the net, or rather, part of its structure will be diminished. They make connections at the end of the network with other groups. They have great importance because information or contents of great value may go through them, as they are not redundant (Granovetter, 1973; Burt, 1992; Scott, 1987; Brass; Burkhardt, 1998).

The intermediate centrality (betweenness) measures the extent to which an actor without much expression, with low contact (degrees), may have on the network, for being an actor of contacts among the rest. An actor between two other actors for a given path without alternative deviations creates a dependency on him and play with this force. The larger the group that comes after this actor, the greater its value on the net (Scott, 1987).

Considering all these listed indicators and based on the propositions of Antonialli (2000) and Carvalho (2003), it may be supposed that the density degree, cohesion index, intermediate centrality and centralization degree are low. On the other hand, the geodesic distance and network diameter are high. 


\section{METHOD}

Current descriptive research analyzes the characteristics of the relationships between the actors and identifies the contents of the existing relations. It is also a quantitative research. The units of analysis comprised 148 cooperatives in the dairy segment of Minas Gerais, Brazil. The elements under observation comprised leaders, or rather, presidents, vice presidents, directors, deputy directors, managers and / or administrators.

Ucinet 6.0 and NetDraw were employed to set the parameters of centrality, density, number of links, network diameter, cohesion index, middle distance, betweenness and border expander. Ucinet analyzes data collected in the survey and measures parameters that make up the network. Measurements are the structural positioning and the interaction of actors in the network. Netdraw visualizes the graph of the network, its internal composition, connections, actors and paths or non-directional.

\section{RESULTS}

At this stage, the data from questionnaires of 148 dairy cooperatives in Minas Gerais were analyzed. Each cooperative received a code number (C1 to C148) to protect sources of information. The sociogram was prepared from the questionnaire in which the respondent had to inform the cooperatives, in order of importance, with which he maintained contact. After data collection, analysis and construction of the measurements of network events were undertaken.

\subsection{DENSITY DEGREE}

Only 275 from 21,904 possible ties in the network of 148 dairy cooperatives were hired, at the low density of $1.26 \%$. Result shows the low relationship pattern between the surveyed cooperatives, hindering the flow of information. Since no contact exists, there is a considerable loss of social capital (Burt, 1992; Granovetter 
1973; Coleman et al, 1988).

According to several authors, specifically Granovetter (1973) and Burt (1992), the companies that provide consistent and larger networks may have access to valuable information and transform it into positive results for their benefit. Therefore, cooperatives are missing opportunities to achieve good results in their several businesses. Data is also aligned with the opinion of Antonialli (2000), according to whom cooperatives on the market are isolated and losing competitiveness.

\subsection{CENTRALIZATION DEGREE (FREEMANS)}

The network centralization degree, considering the output, was 7.631\%; 9.686\% when inputs are considered. Both indexes are low and reveal dispersion of contacts within the studied network. With regard to the actors' specific measures of centrality, Table 1 shows the main central actors who act as the central network connectors.

Table 1. Degree of input and output (asymmetric model) - Key actors

(Continua)

\begin{tabular}{ccccc}
\hline Actor $(\mathbf{C})$ & OutDegree & InDegree & NrmOutDeg* & NrmInDeg** $^{*}$ \\
\hline 83 & 13.000 & 1.000 & 8.844 & 0.680 \\
48 & 13.000 & 3.000 & 8.844 & 2.041 \\
1 & 12.000 & 9.000 & 8.163 & 6.122 \\
55 & 11.000 & 0.000 & 7.483 & 0.000 \\
2 & 11.000 & 10.000 & 7.483 & 6.803 \\
119 & 9.000 & 0.000 & 6.122 & 0.000 \\
4 & 8.000 & 6.000 & 5.442 & 4.082 \\
67 & 7.000 & 1.000 & 4.762 & 0.680 \\
25 & 7.000 & 6.000 & 4.762 & 4.082 \\
80 & 6.000 & 0.000 & 4.082 & 0.000 \\
5 & 6.000 & 6.000 & 4.082 & 4.082 \\
77 & 6.000 & 3.000 & 4.082 & 2.041 \\
109 & 6.000 & 1.000 & 4.082 & 0.680 \\
102 & 6.000 & 2.000 & 4.082 & 1.361 \\
\hline
\end{tabular}


(Continua)

\begin{tabular}{|c|c|c|c|c|}
\hline Actor (C) & OutDegree & InDegree & NrmOutDeg* & NrmInDeg** \\
\hline 92 & 6.000 & 2.000 & 4.082 & 1.361 \\
\hline 16 & 6.000 & 0.000 & 4.082 & 0.000 \\
\hline 50 & 5.000 & 1.000 & 3.401 & 0.680 \\
\hline 3 & 5.000 & 4.000 & 3.401 & 2.721 \\
\hline 33 & 5.000 & 1.000 & 3.401 & 0.680 \\
\hline 94 & 5.000 & 0.000 & 3.401 & 0.000 \\
\hline 117 & 5.000 & 0.000 & 3.401 & 0.000 \\
\hline 54 & 5.000 & 1.000 & 3.401 & 0.680 \\
\hline 65 & 5.000 & 0.000 & 3.401 & 0.000 \\
\hline 42 & 4.000 & 0.000 & 2.721 & 0.000 \\
\hline 32 & 4.000 & 3.000 & 2.721 & 2.041 \\
\hline 14 & 4.000 & 0.000 & 2.721 & 0.000 \\
\hline 101 & 4.000 & 1.000 & 2.721 & 0.680 \\
\hline 17 & 4.000 & 2.000 & 2.721 & 1.361 \\
\hline 15 & 4.000 & 3.000 & 2.721 & 2.041 \\
\hline 49 & 3.000 & 3.000 & 2.041 & 2.041 \\
\hline 30 & 3.000 & 0.000 & 2.041 & 0.000 \\
\hline 10 & 3.000 & 2.000 & 2.041 & 1.361 \\
\hline 39 & 3.000 & 0.000 & 2.041 & 0.000 \\
\hline 107 & 3.000 & 2.000 & 2.041 & 1.361 \\
\hline 99 & 3.000 & 0.000 & 2.041 & 0.000 \\
\hline 60 & 3.000 & 2.000 & 2.041 & 1.361 \\
\hline 19 & 3.000 & 2.000 & 2.041 & 1.361 \\
\hline 75 & 3.000 & 2.000 & 2.041 & 1.361 \\
\hline 20 & 3.000 & 0.000 & 2.041 & 0.000 \\
\hline 96 & 3.000 & 0.000 & 2.041 & 0.000 \\
\hline 59 & 3.000 & 1.000 & 2.041 & 0.680 \\
\hline 24 & 3.000 & 7.000 & 2.041 & 4.762 \\
\hline 118 & 3.000 & 2.000 & 2.041 & 1.361 \\
\hline 6 & 3.000 & 16.000 & 2.041 & 10.884 \\
\hline 147 & 3.000 & 0.000 & 2.041 & 0.000 \\
\hline 37 & 3.000 & 2.000 & 2.041 & 1.361 \\
\hline
\end{tabular}


(Conclusão)

\begin{tabular}{ccccc}
\hline Actor $(\mathrm{C})$ & OutDegree & InDegree & NrmOutDeg* $^{*}$ & NrmInDeg*** $^{* *}$ \\
\hline 103 & 3.000 & 0.000 & 2.041 & 0.000 \\
11 & 3.000 & 2.000 & 2.041 & 1.361 \\
93 & 3.000 & 1.000 & 2.041 & 0.680 \\
\hline
\end{tabular}

* Normalized out-degrees; ** Normalized in-degrees.

Table 2 shows descriptive statistics of centralization measures, highlighting the average of contacts, or rather, 1.858 (input and output).

Table 2. Descriptive Statistics

\begin{tabular}{llcccc}
\hline & & $\mathbf{1}$ & $\mathbf{2}$ & $\mathbf{3}$ & $\mathbf{4}$ \\
\hline & & OutDegree & InDegree & NrmOutDeg* $^{*}$ & NrmInDeg** $^{* *}$ \\
\hline 1 & Mean & 1.858 & 1.858 & 1.264 & 1.264 \\
2 & Standard Deviation & 2.869 & 2.196 & 1.952 & 1.494 \\
3 & Sum & 275.000 & 275.000 & 187.075 & 187.075 \\
4 & Variance & 8.230 & 4.824 & 3.809 & 2.233 \\
5 & SSQ & 1.729 .000 & 1.225 .000 & 800.130 & 566.893 \\
6 & MCSSQ & 1.218 .020 & 714.020 & 563.663 & 330.427 \\
7 & Euc Norm & 41.581 & 35.000 & 28.287 & 23.810 \\
8 & Minimum & 0.000 & 0.000 & 0.000 & 0.000 \\
9 & Maximum & 13.000 & 16.000 & 8.844 & 10.884 \\
\hline
\end{tabular}

* Normalized out-degrees; ** Normalized in-degrees.

Actors with higher rates than average centrality are the most important in the network because they are the most central and information brokers. Forty-nine players were selected as central connectors (Table 1). The sum of rates of standard input and output degrees is compared with the sum of the mean input and output rates. Among the most central actors, C2, C1, C6, C48, C83 and C4 had the highest percentage of input and output degree and thus highlighted.

The output degree indicates cooperatives with more contacts. They have greater capabilities to communicate with others and are most effective in absorbing knowledge. Further, a large concentration of output degree in some cooperatives, 
namely, C48, C83, C1, C2, C55 and C119, shows that they are more likely to initiate contacts. They form a group with higher chances in communication, since the greater the degree of output, the greater the power of the actor to be in contact with the flow of information (Wasserman \& Faust, 2006).

The case of cooperative C6 with its high input degree, $10,884 \%$, and a relatively small degree of output of $2.041 \%$ is worth mentioning. This means that it provides a low rate of communication and, therefore, it is considered a passive and closed organization. According to Coleman (1988), Lin (1999), Burt (1992) and others, albeit belonging to a network, it is important to know how to take advantage from such a fact. Cooperative C6 did not profit from such benefits: it could not bring together stakeholders around a group; it did not further ideas and may not be considered a diffuser of information.

Analyzing the standard degree of input (NrmInDeg - last column of Table 1) and the percentages of centrality input, cooperatives $\mathrm{C} 2$, with $6.803 \%$; $\mathrm{C} 1$, with 6.122\%; and C26, with 5.442\% may be underscored. According to several authors, such as Wasserman, Faust, (2007); Granovetter (1973) and Burt (1992), these cooperatives have higher chances of success, since they communicate more and more and have more access to information. They have greater chances for innovation and opportunities.

\subsection{GEODESIC DISTANCE, DIAMETER AND NETWORK COHESION}

The Geodesic Distance indicates the shortest path between two actors. For each pair of nodes (actors), the software finds the shortest path between them (adjacent data). In the case of the network of cooperatives under analysis, the average distance between reachable pairs $\{$ (Average distance (among reachable pairs) $\}$ is 3.063. This means that, on average, the actors have to go through 3.063 contacts to connect up.

The network diameter is provided by the largest geodesic distance, or rather, the necessary contacts for connecting the two most distant players on the network. Table 3 shows the occurrence of contacts according to the minimum number of steps. There are six actors distant eight steps from each other. Therefore, 
the diameter of the network is eight steps, required to connect the most distant players on the network.

Table 3. Cohesion of Sociometric Network

\begin{tabular}{lcc}
\hline & Frequency & Proportion \\
\hline 1 & 274.000 & 0.153 \\
2 & 438.000 & 0.244 \\
3 & 453.000 & 0.252 \\
4 & 342.000 & 0.190 \\
5 & 154.000 & 0.086 \\
6 & 93.000 & 0.052 \\
7 & 36.000 & 0.020 \\
8 & 6.000 & 0.003 \\
\hline
\end{tabular}

Moreover, the distance-based cohesion (Compactness) $=0.036$. Cohesion varies from 0 to 1 : the larger the rate, the greater is the degree of cohesion. Thus, cohesion rate 0.036 is considered very low, or rather, relationships of the cooperatives are not very cohesive and the network does not have very strong ties. Therefore, it will be difficulty to use this network to start mobilization in favor of some activity. On the other hand, if the cooperatives initiate more contacts among themselves, they could obtain more results. According to Granovetter (1973) and Burt (1992), these contacts would be fruitful, rich in information and full of novelties. They are not redundant since the cooperatives do not belong to the same group and lack closeness.

\subsection{INTERMEDIATE CENTRALITY (BETWEENNESS)}

Due to the low level of contacts between cooperatives and to low density, there is a low intermediation rate by the actors, indicated by the index of centralization of the network (Network Centralization Index) $=2.44 \%$.

Table 4 shows cooperatives with the position of intermediating information flow, benefiting from the privilege of receiving faster information. Only 27\% of the cooperatives were able to perform this role, albeit with low efficiency in intermediation due to the network's low density. 
Table 4. Cooperatives with greater intermediation capacity

\begin{tabular}{|c|c|c|}
\hline Actor (C) & Betweenness & nBetweenness \\
\hline 1 & 546.186 & 2.545 \\
\hline 25 & 352.160 & 1.641 \\
\hline 2 & 347.417 & 1.619 \\
\hline 19 & 239.000 & 1.114 \\
\hline 15 & 215.000 & 1.002 \\
\hline 83 & 206.786 & 0.963 \\
\hline 4 & 192.205 & 0.896 \\
\hline 10 & 191.333 & 0.891 \\
\hline 3 & 157.000 & 0.732 \\
\hline 17 & 127.000 & 0.592 \\
\hline 48 & 109.000 & 0.508 \\
\hline 24 & 108.276 & 0.505 \\
\hline 6 & 95.167 & 0.443 \\
\hline 5 & 94.576 & 0.441 \\
\hline 11 & 78.250 & 0.365 \\
\hline 118 & 76.500 & 0.356 \\
\hline 92 & 75.000 & 0.349 \\
\hline 49 & 72.500 & 0.338 \\
\hline 77 & 62.500 & 0.291 \\
\hline 102 & 58.726 & 0.274 \\
\hline 34 & 51.000 & 0.238 \\
\hline 54 & 44.000 & 0.205 \\
\hline 18 & 34.000 & 0.158 \\
\hline 107 & 25.500 & 0.119 \\
\hline 33 & 24.000 & 0.112 \\
\hline 37 & 22.250 & 0.104 \\
\hline 50 & 22.000 & 0.103 \\
\hline 109 & 20.000 & 0.093 \\
\hline
\end{tabular}

Boundary expanders (cutoff)

Forty-nine boundary expanders or cuttoff actors were detected. Their role consists in connecting a group of actors to another group, creating a path between them through which information passes. If the network misses the boundary expanders, it will lose the other actors linked by them; its size will be reduced; 
and risks losing stakeholder groups that are contributing with non-redundant information. In the amount of cutoff actors, the following boundary expanders were identified: C1, C2, C3, C4, C6, C10, C14, C17, C18, C21, C23, C33, C34, C40, C48, C50, C52, C54, C55, C61, C65, C75, C77, C80, C83, C92, C94, C101, C107, C109, $\mathrm{C} 121$ and $\mathrm{C} 124$.

Figure 1 shows the boundary expanders and the actors performing the roles of expanders, brokers and central connectors.

Moreover, Figure 1 also reveals cooperatives that stand out on the network by simultaneously occupying the positions of connectors, expanders and information brokers. These actors are strategically positioned in relation to others because they can raise capital on the network. Therefore, according to theory by Burt (1992), Granovetter (1973) and Coleman (1988), due to the position they occupy, these cooperatives may be having a greater competitive advantage than their peers, because they play a central role in the network, receiving, sending and managing information.

Figure 1 also revealed that there is a structural gap between the principal group and the group made up of the cooperatives C62, C63 C64 and C61. In this case, their effort and that of other cooperatives would be critical for the merging of these cooperatives into the main group.

\subsection{CLIQUES}

Cliques are close actor groups, more committed to each other since they are all interconnected and they interact directly with each other. In this particular case, these groups may be the members of central cooperatives or their potential members. These subgroups on the network may greatly influence inside communication, and when forming a cohesive group with shared positions, they may play an influential role as opinion-formers within the network as a whole.

Forty-six sub-groups were detected, with three members forming cliques. Five cliques were found with four members (Figure 1), formed by the following cooperatives: 

1: $\mathrm{C} 1, \mathrm{C} 2, \mathrm{C} 4, \mathrm{C} 5$ and $\mathrm{C} 16$
2: $\mathrm{C} 1, \mathrm{C} 2, \mathrm{C} 3$ and $\mathrm{C} 4$
3: $\mathrm{C} 1, \mathrm{C} 2, \mathrm{C} 4$ and $\mathrm{C} 6$
4: $\mathrm{C} 1, \mathrm{C} 7, \mathrm{C} 25$ and $\mathrm{C} 83$
5: C33, C34, C36 and C54

The position of cooperatives $\mathrm{C} 2, \mathrm{C} 4$ and mainly $\mathrm{C} 1$ with participation in different cliques is worth noting.

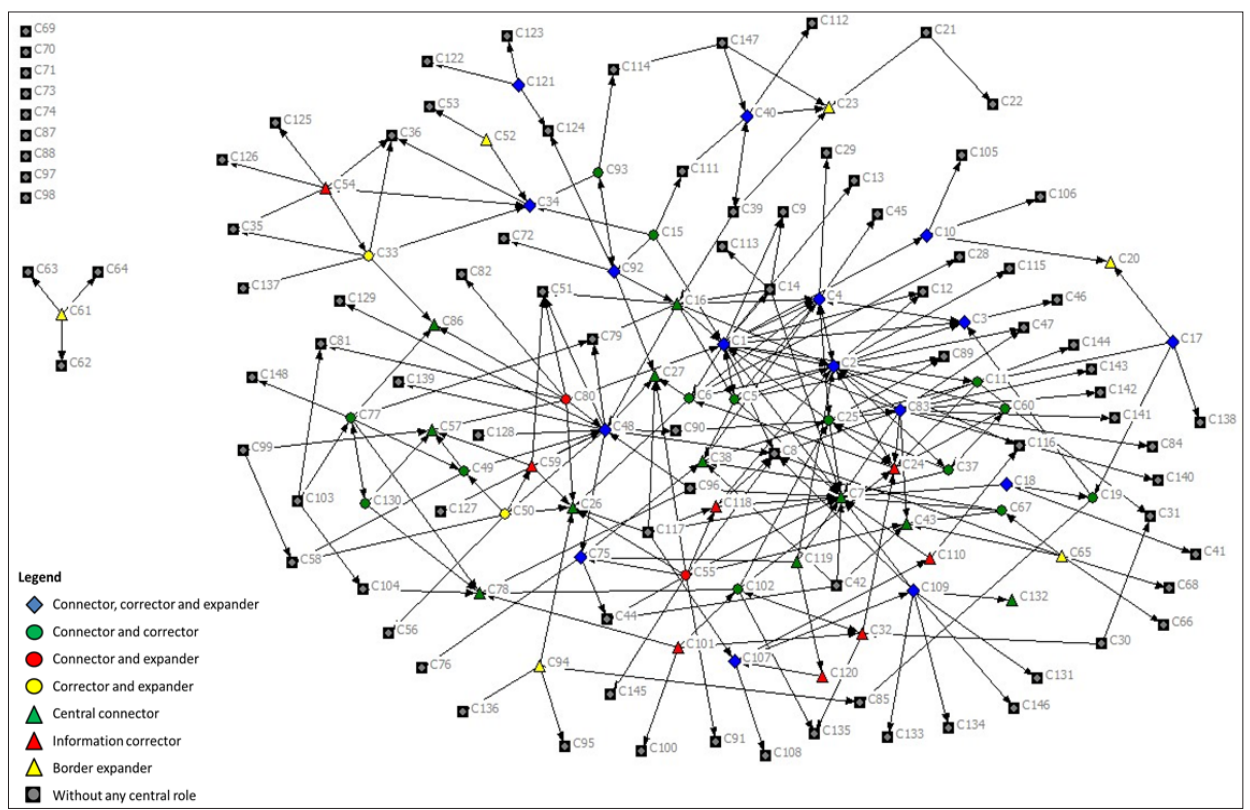

Figure 1. Network sociometric highlighting connectors, brokers and expanders

\subsection{ANALYSIS OF COOPERATIVE TIES IN THE STATE OF MINAS GERAIS, BRAZIL}

The current analysis was based on answers with regard to the frequency of contacts. For the analysis of ties, the premise of Granovetter (1973) was used. Strong ties are those maintained by frequent contacts, or rather, with contacts two or more times per week. Weak ties are occasional contacts, occurring less than twice a week and at least two or more times a year. Tables 5, 6, 7, 8 and 9 show the main findings. 
Table 5. We have meetings with the cooperatives with which we maintain contact

\begin{tabular}{cccccc}
\hline & & Frequency & Percent & Valid Percent & Cumulative Percent \\
\hline \multirow{3}{*}{ Valid } & Yes & 196 & 59.2 & 62.6 & 62.6 \\
& No & 117 & 35.3 & 37.4 & 100.0 \\
\multirow{3}{*}{ Missing } & Total & 313 & 94.6 & 100.0 & \\
\hline & & 18 & 5.4 & & \\
\hline
\end{tabular}

Results show that $62.6 \%$ of respondents reported that they hold formal meetings with whom they maintain contacts; the other $37.5 \%$ did not have any meetings. Therefore, a large percentage does not have any formal contact with those with whom they talk. According to Granovetter (1973); Burt (2000), Coleman et al. (1988), this undermines trust and the sharing of relevant information for those involved.

Table 6. We hold more than two meetings per month with cooperative members

\begin{tabular}{|c|c|c|c|c|c|}
\hline & & Frequency & Percent & Valid Percent & Cumulative Percent \\
\hline \multirow{3}{*}{ Valid } & Yes & 272 & 82.2 & 85.8 & 85.8 \\
\hline & No & 45 & 13.6 & 14.2 & 100.0 \\
\hline & Total & 317 & 95.8 & 100.0 & \\
\hline \multirow[t]{2}{*}{ Missing } & System & 14 & 4.2 & & \\
\hline & Total & 331 & 100.0 & & \\
\hline
\end{tabular}

Approximately $86 \%$ of respondent cooperatives said they hold frequent meetings with members, and only $14 \%$ do so sporadically. Following Granovetter (1973), the ties are not weak and trust exists, even though there is a greater chance of redundancy. Approach conceived by Burger and Buskens (2009) also applies, or rather, dense networks with frequent contacts signify greater synergy. This fact occurs in cooperatives that maintain constant contact with members, whether through formal meetings or casual gatherings on their premises or even in their stores, factories etc.

When comparing the previous questions, it may be detected that there 
is a higher frequency of meetings between members and leaders than between cooperatives through their managers.

Table 7. I usually talk at least twice a week with people from other dairy cooperatives with whom I have contact

\begin{tabular}{|c|c|c|c|c|c|}
\hline & & Frequency & Percent & Valid Percent & Cumulative Percent \\
\hline \multirow{3}{*}{ Valid } & No & 236 & 71.3 & 74.9 & 74,9 \\
\hline & Yes & 79 & 23.9 & 25.1 & 100,0 \\
\hline & Total & 315 & 95.2 & 100.0 & \\
\hline Missing & System & 16 & 4.8 & & \\
\hline \multicolumn{2}{|c|}{ Total } & 331 & 100,0 & & \\
\hline
\end{tabular}

Data reveal that the managers of the cooperative network do not communicate with high frequency, whereas approximately $75 \%$ do not fit the category of strong ties conceived by Granovetter (1973) since they do not connect more than twice a week.

Table 8. I speak more than once a year and less than twice a week with cooperatives that I keep in touch with

\begin{tabular}{|c|c|c|c|c|c|}
\hline & & Frequency & Percent & Valid Percent & Cumulative Percent \\
\hline & Yes & 250 & 75.5 & 80.4 & 80,4 \\
\hline \multirow[t]{2}{*}{ Valid } & No & 61 & 18.4 & 19.6 & 100,0 \\
\hline & Total & 311 & 94.0 & 100.0 & \\
\hline Missing & System & 20 & 6.0 & & \\
\hline & & 331 & 100,0 & & \\
\hline
\end{tabular}

Results suggest that most cooperatives ties (80.4\%) may be classified as weak ties, within the concept of Granovetter (1973). Therefore, they have the benefits of social capital: since contact is infrequent, whenever they meet or talk, they have new information. However, weak ties reduce trust in the case of groups of companies trying to join forces or coalesced LPA (Local Productive Arrangement) or central cooperatives (Coleman, 1988). In the case of LPA, strong ties are important because they bring greater results in terms of commitment and coercion will have 
more effect (Burger and Buskens, 2009) and lower transaction cost (Williamson, 1994). Furthermore, strong ties increase the speed of communication, trust and commitment.

Table 9. I speak once a year or less with contacts in other cooperatives

\begin{tabular}{|c|c|c|c|c|c|}
\hline & & Frequency & Percent & Valid Percent & Cumulative Percent \\
\hline \multirow{3}{*}{ Valid } & No & 203 & 61.3 & 64.4 & 64,4 \\
\hline & Yes & 112 & 33.8 & 35.6 & 100,0 \\
\hline & Total & 315 & 95.2 & 100.0 & \\
\hline Missing & System & 16 & 4.8 & & \\
\hline \multicolumn{2}{|c|}{ Total } & 331 & 100,0 & & \\
\hline
\end{tabular}

These data indicate that the leaders speak once a year or less with other cooperatives, maintaining weak ties (GRANOVETTER, 1973).

When the above data on external (between cooperatives) and internal contacts (contacts with cooperative members) are taken into consideration, it may be concluded that there are more chances to build strong ties with members than with managers of other cooperatives. Maybe that is a major factor in the relationship between members and managers of cooperatives. In fact, there is a great trust between them, which, according to Granovetter (1973), demonstrates the existence of strong ties. Considering observations by Granovetter (1973) and Burt (1992), who claim that the information exchanged between network operators in these conditions is redundant and does not generate innovations, it is important to establish contacts with other cooperatives for new opportunities. According to Antonialli (2000), cooperatives must come out of their isolation.

\section{FINAL REMARKS}

Results demonstrate the need to develop a social network of inter-state cooperatives in the state of Minas Gerais, Brazil. Something new could be structured to minimize barriers that keep cooperatives apart from each other, with the elimination of structural gaps and asymmetry between input and output contacts. Current 
authors suggest that a leadership (such as the State Cooperative Organizations) fulfill this role and develop a robust plan, with adequate tools to facilitate learning and the construction and maintenance of inter-organizational social networks. They will surely produce a highly positive effect on the whole network.

The dissemination of the concept of inter-organizational networks via working groups for the microregion may also be suggested, in which cooperatives of a particular area could meet and develop the precepts of social networks. These working groups could be initially established and led by cooperatives which already play central roles on the network. After a certain period, they could join work at the macroregion level, when the regional groups would already be stronger and aware of the importance of networking. Small groups of cooperatives would establish an important element in networks: power and trust, making it easier to implement the concept in the cooperatives that are further away in the network.

As an academic contribution, the development of a sociogram and the identification of relationship features for an important sector in Brazilian economic environment should be highlighted.

Further studies are recommended to test this model in other segments of cooperatives and with cooperatives from other Brazilian states to see whether they also have similar inter-organizational behavior with regard to social networking.

Another suggestion would be to measure social capital in the network and to establish when the generator of this capital occurs, or rather, to identify when ties are weak and when they are strong and when weak ties are more important than strong bonds and vice versa.

\section{REFERENCES}

ANTONIALLI, L. M. Modelo de gestão e estratégias: o caso de duas cooperativas mistas de leite e café de Minas Gerais. 2000. 163f. Doctoral (Thesis in Administração) - Faculdade de Economia, Administração e Contabilidade da Universidade de São Paulo, São Paulo, 2000.

BALANCIERI, R. Um método baseado em ontologias para explicitação de 
conhecimento da análise de redes sociais de um domínio de aplicação. 2010. Doctoral (Thesis in Engineering and Knowledge Management) - UFSC, Florianópolis, 2010.

BARNEY, J. B.; WRIGHT, M.; KETCHEN, J. The resource-based view of the firm: ten years after 1991. Journal of Management. p. 625-641, 2001.

BRASS, D. J.; BURKHARDT, M. E. Centrality and Power in Organizations. 5. ed. Networks and Organizations, Structures, Form, and Action. Edited by Nitin Nohria and Robert G. Eccles. Boston: Harvard Business School Press. 1998.

BURGER, M. J. BUSKENS, V. Social context and network formation: an experimental study. Retrieved on: 02/feb./2011. from: < http://repub.eur.nl/res/ pub/14138/>. 2009.

BURT, R. S. The social structure of competition. In: NOHRIA, N.; ECCLES, R. G. Networks and organizations: structure, form, and action. Boston: Harvard Business School Press. 1992.

BURT, R. S. The new structure of social capital. JAI Press. 2000.

CARVALHO, M. P. de. Cooperativismo lácteo no Brasil: desafios e oportunidades. Retrieved on: 12/feb./2011, from: < http://www.milkpoint.com.br/mercado/artigosespeciais/Cooperativismo-lacteo-no-brasil-desafios-e-oportunidades-8625n.aspx $>$. 2003.

CASTELLS, M. A Sociedade em Rede: do conhecimento à política;

Conferência. Belém (Por): Imprensa Nacional, <http://www.egov.ufsc.br/portal/ conteudo/sociedade-em-rede-do-conhecimento-\%C3\%A0-ac\%C3\%A7\%C3\%A3opol\%C3\%ADtica>. 2005.

GRANDORI, A.; SODA, G. Inter-firm networks: antecedents, mechanisms and forms. Organization Studies, v.15, n. 2, p.1-19, 1995.

GRANOVETTER, M. S. The strenght of weak ties. American Journal of Sociology. v. 6 , p. $1360-1380,1973$. 
GRANOVETTER, M. S. Economic Action and Social Structure: The Problem of Embeddedness. Retrieved on: 06/Jul./2011, from: < http://sd-5.archive-host.com/ membres/up/3262206863616248/Granovetter_1985.pdf>. 1985.

HUMMON, N. P.; DOREIAN, P.; FREEMAN, L. C. Analyzing the Structure of Centrality: Productivity Literature Created Between 1948 and 1979. Knowledge. v. 11, n. 4, p. 459-480, june. 1990.

KRACKHARDT, D. The Strength of Strong Ties: The Importance of Philos in Organizations, Networks and Organizations, Structures, Form, and Action. 5. ed. Edited by Nitin Nohria and Robert G. Eccles. Boston: Harvard Business School Press. 1998.

LEAVITT, H. J. Some Effects of Communication Patterns on Group Performance, Journal of Abnormal and Social Psychology, v. 46, p. 38-50, 1951.

LIN, N. Social Resources and Instrumental Action. in Social Structure and Network Analysis, edited by Peter V . Marsden and Nan Lin. Beverly Hills, CA: Sage. 1982.

LIN, N. Building a Network Theory of Social Capital. Retrieved on 16/oct./2011, from: < http://citeseerx.ist.psu.edu/viewdoc/ download?doi $=10.1 .1 .96 .3792 \& \mathrm{rep}=$ rep1\&type $=\mathrm{pdf}>.1999$.

MARSDEN, P. V. Network Data and Measurement. Retrieved on 16/oct./2011, from: $<$ http://www.annualreviews.org/doi/pdf/10.1146/annurev.so.16.080190.002251>. 1990.

MARSDEN, P. V. The Reliability of Network Density and Composition

Measures. Retrieved os 16/oct./2011, from: < http://publicdata.norc.org:41000/gss/ DOCUMENTS/REPORTS/Methodological_Reports/MR072.pdf>. 1992.

MARSDEN, P. V. Interviewer effects in measuring network size using a Single name generator. Retrieved on 16/oct./2011, from:

< http://courses.gov.harvard.edu/gov3009/spring01/marsden.pdf>. 2001.

MORENO, J. L. Quem sobreviverá? Fundamentos da sociometria, psicoterapia de 
grupo e sociodrama. Goiânia: Dimensão. 1953.

NOHRIA, N.; ECCLES, R. G. Networks and organizations: structure, form, and action. Harvard Business School Press, Boston: Massachusetts. 1992.

OCB - Organização das Cooperativas Brasileiras. Cooperativismo. Ribeirão Preto: Versão Br Comunicação e Marketing. 2004.

OLIVEIRA, D. P. R. Manual em gestão de cooperativas: uma abordagem prática. 2. ed. São Paulo: Atlas. 2003.

SCOTT, J. Social Network Analysis: A Handbook. London: Sage Publications. 1987.

VALE, G. M. Vasconcellos. Laços como ativos territoriais: uma nova abordagem para o desenvolvimento. RDE-Revista Desenvolvimento Econômico, v. 8, n. 14, 2006.

WASSERMAN, S.; FAUST, K. Social network analysis: methods and applications. 17th printing. New York: Cambridge University Press. 2007.

WILLIAMSON, O. E. The economic of organization: the transaction cost approach. American Journal of Sociology, p. 548 -577. 1981.

\section{WILLIAMSON, O. E. Research Needs and Opportunities in Transaction Cost}

Economics. Retrieved on: 05/ago./2011, from: < http://web.cenet.org.cn/ upfile/12343.pdf>. 1994.

Recebido em: 01/03/2016 Aceito em: 24/05/2018 